\title{
A Principal Component Analysis Approach to Measure Contributions of Shinkin Banks to Regional Economies in Northeast Area of Japan
}

\author{
Hideo SATo ${ }^{1}$, Yanwen Dong ${ }^{2}$, and Vinod Kumar ${ }^{3}$ \\ ${ }^{1}$ Graduate School of Symbiotic Systems Science, Fukushima University, Fukushima City, 960-1296, Japan \\ ${ }^{2}$ Cluster of Science and Technology, Fukushima University, Fukushima City, 960-1296, Japan \\ ${ }^{3}$ Sprott School of Business, Carleton University, Ottawa, Ontario K1S 5B6, Canada
}

\begin{abstract}
As one kind of regional finance institutions (RFIs), shinkin banks have closer relations with development of regional economies than city banks. This paper aims to apply principal components analysis to evaluate the performance of shinkin banks' contribution to regional economies in northeast area of Japan. Different from the existing studies, this paper is the first attempt to use principal components analysis to analysis of shinkin banks. Meanwhile, we limit our analysis to 27 shinkin banks in the northeast area of Japan and put our emphasis on extracting an effective indicator to measure the contributions of the shinkin banks to regional economies and clarify the issues for the shinkin banks to improve or strengthen their regional contribution.
\end{abstract}

Key Words : Regional Finance, Shinkin Bank, Regional Economy, Regional Contribution, Multivariate Analysis.

\section{Introduction}

\subsection{Shinkin Banks and Regional Economies}

The Japanese banking system consist of different kinds of financial institutes, including big commercial city banks, trust banks, regional banks, and shinkin banks. Differing from city banks and regional banks that both of them are corporations licensed under the Bank Law, shinkin banks are cooperatives of small and medium sized enterprises (SMEs) licensed under the Shinkin Bank Law. Shinkin banks resemble U.S. credit unions, their business operations are limited strictly into a narrow area such as a few cities, and/or a few towns, and they are not permitted to open a branch out of their licensed area. Shinkin banks make loans primarily to residents and SMEs within their licensed area, but they can accept deposits from anyone.

As of June 2015, shinkin banks have 7,396 branches, more than 9.28 million of memberships, and it is the biggest branch network in Japan. To qualify for membership a firm must have no more than 300 employees or a capitalization no more than 900 million Japanese yen. There were 267 Shinkin banks at the end of 2014 (compared to 480 in 1980) with a loan share of $12.45 \%$ and a deposit share of $11.39 \%$ in Japanese financing service market.

According to the Small and Medium Enterprise Agency of Japan, there are 4.69 million of SMEs in Japan, constituting $99.7 \%$ of all enterprises, accounting for $70 \%$ of whole employment. SMEs form the framework of the Japanese economy, and in particularly they play a very important role in the Japanese regional economy development. As one kind of regional finance institutions (RFIs), shinkin banks have closer re-

Corresponding Author: Yanwen Dong

Cluster of Science and Technology, Fukushima University, No.1, Kanayagawa, Fukushima City, 960-1296 Japan

dong@sss.fukushima-u.ac.jp

(Received September 25, 2015)

(Revised January 16, 2016)

(Accepted March 15, 2016) lations with development of regional economy than city banks. Shinkin banks thus have an essential mission to provide financial services of a universal character, and bringing them closer to SMEs and citizens through different distribution channels. Through their financial services, shinkin banks can provide an impulse to economic and financial development in their areas of action, avoid social and financial exclusion, and return the profits they make to society. As shinkin banks are restricted by regulation to make loans only to local SMEs and individuals, the performances of shinkin banks can be regarded as an indicator of local business developments.

\subsection{Literature Review}

Because of the deep relationship between shinkin banks and regional economies, many Japanese researchers have paid their attentions to shinkin banks and published a lot of literature in Japanese language. These researches have examined shinkin banks mainly from the following three viewpoints.

(1) Relation to regional economies: Takigawa [1] defined "Regional Bank" based on three measures (inner-regional lending rate, inner-regional branch rate, inner-regional reflux rate) and constructed an analytic model. He insists that maximizing regional banks' utility depend on not only profit but also inner-regional lending rate. Iwasa [2],[3] gave a sociological discussion on the role of regional banks to induce disparities among regions. Yoshihara [4] collected the performance data of 294 shinkin banks as of March 2006, and investigated the correlation between the shinkin banks' performance and the economy index of the regions where the shinkin banks located, but he could not find any significant correlation relation. On the other hand, Horie [5] showed that there is a significant relation between shinkin banks' operation areas and their profitability.

(2) Deflation and default of shinkin banks: Several studies 
have contributed to the default analysis of shinkin banks. Recently, Ishikawa [6] gave a detailed examination on the management behaviors and various factors that caused Sogo Shinkin Bank' failure. Shimabukuro [7] conducted an empirical analysis on the causes of shinkin banks' failure and showed that Heisei-Depression (the long stagnation in the 1990s) has given stronger influence on the shinkin banks' failure than the collapse of the bubble economy in Japan from 1986 to 1991.

(3) Analysis of profitability or other performance measures: there are many reports to analyze shinkin banks' performance or compare them with city banks and other kind of financial institutes. Horie [8] gave several reports on shinkin banks' performance analysis and his recent study investigated the influence of distressed assets' disposal on profitability of shinkin banks. He showed that shinkin banks have to use more than $50 \%$ of their profit for distressed assets' disposal. Kozuka [9] applied impulse response function to examine the lending behaviors of shinkin banks and other Japanese financial institutes, and clarified that there were some difference in the lending behaviors to SMEs between shinkin banks and other Japanese financial institutes.

There are also several studies on Japanese shinkin banks published on international journals. The paper by Yamori, etc.[10] described the latest state of Japanese banks and banking regulations, as well as how Japanese banks have responded to the global financial crisis. Kano and Tsutsui [11] made an attempt to give a geographical segmentation of regional banks and shinkin banks in Japanese bank loan markets, but they could only segment the markets for shinkin banks. On the performance analysis of Japanese banks, Liu and John [12] investigated the profitability of Japanese banks following the major financial crisis. According to their result, well-capitalized, efficient banks, with lower credit risks tend to outperform less capitalized, less efficient counterparts with higher credit risks. Second association regional banks and shinkin banks (but not other ownership types) appear to benefit from diversification advantages. They also investigated the relationship between competition and risk [13]. They suggested that risk varies across different types of Japanese banks over the period 2000-2009. Specifically, nationwide (city and trust) banks are riskier on average than regional banks, tier 2 regional banks, shinkin banks and credit cooperative banks.

Recently, there are two papers published and their focus is directly on the performance analysis of shinkin banks. Assaf, etc.[14] analyzed the productivity and efficiency of shinkin banks and the various prefectures in Japan. They confirmed that the efficiency growth and productivity growth of shinkin banks have not been improved significantly over the period from 2000 to 2006. Dai [15] assessed productivity changes in Japanese shinkin banks during the fiscal years 2001 to 2008 where the Malmquist index was used as the measure of productivity change. His result showed that in the latter half of the study period, productivity has significantly declined, primarily because of deterioration in technical efficiency, but scale efficiency has been significantly improved.

\subsection{Aim and Contribution of This Study}

Although many researches on shinkin banks have been reported, some issues remain to be examined more deeply and detailed.

(1) Many Japanese researchers have put their focus on performance analysis of shinkin banks, but they applied mainly case study methods, or classical business analysis methods such as comparison analysis and trend analysis. With the limit of the research methods, these analyses depend large on the analyzers' experience. It is necessary to apply advanced methods to analyze shinkin banks' performances more deeply.

(2) Several analytical methods such as regression analysis, data envelopment analysis (DEA) have been applied to compare shinkin banks with city banks or other financial institutions. These comparison studies are helpful and useful to comprehend the characteristics and position of shinkin bank industry in Japanese banking system. However, this kind of analysis is too rough to obtain any insight directly available to the management of a shinkin bank.

(3) As shinkin banks have deep relationship with regional economies, and there are disparities among regions, it is difficult to obtain any meaningful insight if all of shinkin banks are treated just as one homogeneous group. It is necessary to divide shinkin banks into distinctive groups according to their characteristics such as geographical location, capitalization, business environment, etc.

Furthermore, most of Japanese researchers published their reports on Japanese universities' bulletins in Japanese language; it is not easy for the researchers outside Japan to understand these reports.

This study uses Principal Components Analysis (PCA) to evaluate the performance of shinkin banks' contribution to regional economies. We limit our analysis to 27 shinkin banks in the northeast area of Japan and put our emphasis on extracting an effective indicator to measure the contributions of the shinkin banks to regional economies, and clarify the issues for them to improve or strengthen their regional contribution. Comparing to the previous researches, this paper makes the following contributions to the literature.

(1) PCA is a powerful tool for analyzing high-dimensional data. It can identify patterns in data, and express the data in such a way as to highlight their similarities and differences. There are several reports that used PCA for comparing the performance of Chinese banks [16], evaluating on-line banking performance in Taiwan [17], assessing the potential strength of a bank capital channel in Europe [18], assessing the effect on technical efficiency of bad loans in banking industry [19], analyzing bank capital regulation cross-country [20] and etc. However, to our knowledge, PCA has not been used to analyze the performance of shinkin banks, and therefore this study is the first attempt.

(2) We do not treat all of shinkin banks as one homogeneous group to compare them with other kind of financial institutions. We limit our analysis to 27 shinkin banks in the 
northeast area of Japan and furthermore, our object is to clarify the difference among them in performance of regional contribution instead of whole performance analysis.

(3) As our emphasis is different from other researchers, we collect the performance data related to the shinkin banks' regional contribution. Based on the principal component scores, we define an index to measure the shinkin banks' contribution to regional economies.

The rest of the paper is organized as follows: we introduce the shinkin banks to be considered here and give a brief description of their performance data in section 2. At section 3 we conduct the principal components analysis and decide the names of the principal components. After giving some examination and discussion on the PCA results in section 4, we define an index to assess shinkin banks' regional contribution at section 5. Finally, we summarize our research in section 6 and give some concluding remarks.

\section{Shinkin Banks and Their Data}

\subsection{Shinkin Banks}

Two considerations lead us to limit our analysis to the shinkin banks in the northeast area of Japan. The first one is that the northeast area is suffering from the Great East Japan Earthquake Disaster, which occurred on March 11, 2011, and triggered the greatest tsunami ever recorded in Japan and caused tremendous and infinite damage. We intend to examine the state of shinkin banks in this area after the disaster. The second consideration is that the regional economies in the northeast area is comparatively homogeneous and there are fewer disparities among the regions.

According to the above considerations, we chose the following 27 shinkin banks (SBs) from the six prefectures in the northeast area of Japan.

- Fukushima prefecture: Fukushima SB (F1), Himawari SB (F2), Koriyama SB (F3), Siragawa SB (F4), Abukuma SB (F5), Sugakawa SB (F6), Aizu SB (F7), and Nihonmatu SB (F8).

- Miyagi prefecture: Mori No Miyako SB (M1), Ishinomaki SB (M2), Kisennuma SB (M3), Sennan SB (M4), and First Bank Miyashin (M5).

- Iwate prefecture: Morioka SB (I1), Ichinoseki SB (I2), Mizusawa SB (I3), Kitagami SB (I4), Hanamaki SB (I5), and Miyako SB (I6).

- Yamagata prefecture: Tsuruoka SB (Y1), Yonezawa SB (Y2), Yamagata SB (Y3), and Shinjo SB (Y4).

- Akita prefecture: Ugo SB (A1) and Akita SB (A2).

- Aomori prefecture: Aoi Mori SB (A3) and Too SB (A4).

\subsection{Data}

In order to clarify the latest state of 27 shinkin banks' contribution to regional economies and define an effective index to measure their contributions, we choose 26 items of performance that have close relation to regional contributions. We collected these data from the disclosure information of the shinkin banks as of March 31, 2015. These data can be classified into the following six categories.

(1) Performances represented by balance amount

- Deposits balance (DB): Overall amount of deposits balance.

- Regional loans balance (RLB): outstanding loans balance to regional customers excluding local public entities, finance and insurance firms.

- Lending to SMEs (LSME): outstanding loans lent to SMEs.

- Equity capital (EC): Amount of equity capital at the end of fiscal year of 2014 .

- Performing loan (PL): Calculated by subtracting non-performing loans balance from overall loans balance. As some shinkin banks apply partial direct method to write off non-performing loans and the others do not, we added the amount of partial direct write-offs up to non-performing loans.

(2) Performances represented by number

- Number of regional borrowers (NRB): number of borrowers within the business area of each shinkin bank.

- Number of borrowers from SMEs (NBSME): Number of borrowers that is a SME.

- Number of branches (NB).

- Number of permanent officers or employees (NPOE).

(3) Performances represented by ratio (performance of regional financing intermediation)

- Regional loan-deposit ratio (RLDR): the ratio of regional loans balance for overall outstanding deposits balance, $\mathrm{RLDR}=\mathrm{RLB} / \mathrm{DB}$.

- Ratio of regional loans balance (RRLB): the ratio of outstanding loans balance lending to the regional customers for overall outstanding deposits balance.

- Ratio of lending to SMEs (RLSME): ratio of outstanding lending to SMEs for overall outstanding deposits balance.

- Ratio of regional borrowers (RRB): ratio of regional borrowers for overall borrowers.

- Ratio of SMEs (RSME): ratio of SMEs for overall borrowers.

(4) Profit

- Net business profit (NBP): net operating profit.

- Current net profit (CNP): net income in fiscal year.

(5) Safety and soundness

- Overall profit margin (OPM): interest margin for total fund interest rate. 
- Capital-to-asset ratio (CAR): capital adequacy ratio.

- Ratio of performing loan (RPL): ratio of performing loan to overall loan balance or 1- ratio of nonperforming loan (RNPL).

(6) Efficiency

- Return on Asset (ROA): Calculated by dividing a shinkin bank's annual earnings by its total assets.

- Deposits balance per branch (DBPB): Calculated by dividing overall amount of deposits balance by branch number.

- Loans balance per branch (LBPB): Calculated by dividing overall amount of loans balance by branch number.

- Deposits balance per officer or employee (DBPOE): Calculated by dividing overall amount of deposits balance by number of officer or employee.

- Loans balance per officer or employee (LBPOE): Calculated by dividing overall amount of loans balance by number of officer or employee.

- Net business profit per officer or employee (NBPPOE): Calculated by dividing net business profit by number of officer or employee.

- Current net profit per officer or employee (CNPPOE): Calculated by dividing current net profit by number of officer or employee.

\section{Principal Component Analysis}

\subsection{Principal Components Extraction}

Using IBM SPSS Statistics 20.0, we applied the PCA method to the dataset described in the previous section. In order to determine the number of meaningful components, we used the eigenvalue-one criterion. We also used Varimax with Kaiser Normalization as the rotation method to identify the final principal components.

Generally, to make sure that the dataset is suitable for PCA analysis, the overall KMO (the Kaiser-Meyer-Olkin Measure of Sampling Adequacy for the overall dataset) should be above 0.50 , and the Bartlett's test of sphericity should be significant. When applying the PCA method to all of the 26 items of performance measures, we obtained the overall $\mathrm{KMO}=0.161$. Because of this low value of KMO, we removed three performance measures: RRLB, RLSME and RRB, which have low values of communality, from the dataset. Finally, we conducted the PCA based on the 23 items of performance measures, obtained the overall $\mathrm{KMO}=0.554$ and the $p$-value of Bartlett's test of sphericity is $0.0 \%$. These results indicate that the PCA result is admissible on the dataset.

Table 1 shows the main results of the PCA. We could extract five principal components; these components explain together $89.2 \%$ of the global data dispersion. That is, the information contained in the 23 original performance measures can thus be summarized by the five principal components. Among them, the first principal component (PC1) accounts for 36.9\%, and the second principal component (PC2) accounts for $21.8 \%$ of the variance of the 23 original performance measures. The other three components (PC3-PC5) account for 12.9\%, 12.6\% and $5.0 \%$ of the total variance respectively.

\subsection{Naming of Principal Components}

Table 2 shows the structure matrix for the PCA, where large coefficient (the absolute value $>0.45$ ) for each variable to every component are highlighted in bold. As structure matrix represents the correlations between the variables and the principal components, we can interpret the principal components according to these correlation coefficients.

- The first principal component (PC1): PC1 correlates strongly with three performance measures that represent shinkin banks' business sizes: DB (deposits balance), NB (number of branches) and NPOE (number of permanent officers or employees). In addition, it also correlates to four measures that indicate how a shinkin bank has endeavored at region-based relationship banking: RLB (regional loans balance), LSME (lending to SMEs), NRB (number of regional borrowers) and NBSME (number of borrowers from SMEs). PC1 scores are not only proportional to shinkin banks' business sizes but also depend on their achievement of region-based relationship banking. Therefore, PC1 gives a measure of shinkin banks' business size targeting region-based relationship banking. Based on this consideration, we name PC1 the measure of regional financial business size.

- The second principal component (PC2): PC2 positively correlates with CNP (current net profit), CAR (capitalto-asset ratio), DBPOE (deposits balance per officer or employee), and CNPPOE (Current net profit per officer or employee). Meanwhile, it negatively correlates with RLDR (regional loan-deposit ratio). The former four performances express how a shinkin bank could increase its profit and self-owned capital, and obtain deposits efficiently. PC2 scores increase proportionally to increasing of profit and efficiency. The negative relation between PC2 and RLDR means that a shinkin bank can achieve higher score of PC2 through decreasing RLDR (regional loandeposit ratio). We can consider PC2 as a measure whether a shinkin bank has a higher ability to make profit or increase capital not through lending money to regional customers. That is, PC2 indicates the ability of profit making through lending to local public entities, finance and insurance firms. We name PC2 the measure of profit-making ability from non-regional customers.

- The third principal component (PC3): PC3 correlates positively to OPM (overall profit margin), ROA (return on asset) and NBPPOE (net business profit per officer or employee). A shinkin bank can achieve higher score of PC3 if it can manage its funds and make more profit effectively. PC3 provides an indicator to measure the capital efficiency or investment efficiency of a shinkin bank. We name PC3 the measure of capital efficiency.

- The fourth principal component (PC4): PC4 correlates strongly with DBPB (deposits balance per branch) and LBPB (loans balance per branch), and correlates positively with LBPOE (loans balance per officer or employee). As these three performance measures are deposits and loans balance for one branch or one person, it is natural to name PC4 the measure of business efficiency. 
Table 1 Total Variance Explained

\begin{tabular}{|c|r|r|r|r|r|r|}
\hline \multirow{2}{*}{ Component } & \multicolumn{4}{|c|}{ Initial Eigenvalues } & \multicolumn{3}{c|}{ Rotation Sums of Squared Loadings } \\
\cline { 2 - 7 } & Total & \% of Variance & Cumulative \% & Total & \% of Variance & Cumulative \% \\
\hline 1 & 8.629 & 37.519 & 37.519 & 8.480 & 36.871 & 36.871 \\
\hline 2 & 5.201 & 22.612 & 60.131 & 5.019 & 21.822 & 58.693 \\
\hline 3 & 2.995 & 13.024 & 73.155 & 2.970 & 12.912 & 71.605 \\
\hline 4 & 2.575 & 11.197 & 84.352 & 2.896 & 12.591 & 84.195 \\
\hline 5 & 1.109 & 4.821 & 89.173 & 1.145 & 4.978 & 89.173 \\
\hline 6 & 0.804 & 3.494 & 92.667 & & & \\
\hline
\end{tabular}

Table 2 Structure Matrix

\begin{tabular}{|l|r|r|r|r|r|}
\hline \multirow{2}{*}{ Variable } & \multicolumn{5}{|c|}{ Component } \\
\cline { 2 - 6 } & PC1 & PC2 & PC3 & PC4 & PC5 \\
\hline DB & $\mathbf{0 . 9 4}$ & 0.24 & -0.09 & 0.14 & -0.02 \\
\hline RLB & $\mathbf{0 . 9 7}$ & -0.05 & -0.02 & 0.20 & -0.01 \\
\hline LSME & $\mathbf{0 . 9 5}$ & -0.05 & -0.03 & 0.26 & 0.03 \\
\hline EC & 0.45 & $\mathbf{0 . 8 4}$ & -0.04 & 0.06 & -0.01 \\
\hline PL & $\mathbf{0 . 9 4}$ & 0.01 & -0.03 & 0.29 & -0.08 \\
\hline NRB & $\mathbf{0 . 9 7}$ & -0.03 & -0.03 & -0.16 & -0.15 \\
\hline NBSME & $\mathbf{0 . 9 6}$ & -0.07 & 0.00 & 0.03 & 0.10 \\
\hline NB & $\mathbf{0 . 9 1}$ & 0.11 & -0.09 & -0.34 & -0.01 \\
\hline NPOE & $\mathbf{0 . 9 6}$ & -0.04 & -0.14 & -0.13 & -0.07 \\
\hline RLDR & 0.00 & $\mathbf{- 0 . 8 3}$ & 0.39 & -0.03 & 0.00 \\
\hline RSME & -0.31 & 0.06 & -0.08 & 0.28 & $\mathbf{0 . 8 0}$ \\
\hline NBP & $\mathbf{0 . 8 1}$ & 0.16 & 0.41 & 0.13 & -0.03 \\
\hline CNP & 0.25 & $\mathbf{0 . 8 7}$ & 0.17 & 0.05 & 0.00 \\
\hline OPM & -0.01 & -0.13 & $\mathbf{0 . 9 4}$ & -0.12 & -0.06 \\
\hline CAR & -0.34 & $\mathbf{0 . 8 3}$ & -0.04 & -0.14 & 0.07 \\
\hline RPL & -0.23 & -0.03 & -0.04 & 0.52 & $\mathbf{- 0 . 6 6}$ \\
\hline ROA & -0.07 & -0.09 & $\mathbf{0 . 9 5}$ & -0.02 & 0.00 \\
\hline DBPB & 0.08 & 0.35 & -0.20 & $\mathbf{0 . 7 9}$ & 0.03 \\
\hline LBPB & 0.15 & -0.24 & -0.05 & $\mathbf{0 . 9 2}$ & 0.00 \\
\hline DBPOE & 0.01 & $\mathbf{0 . 8 8}$ & 0.02 & 0.43 & 0.07 \\
\hline LBPOE & 0.13 & 0.40 & 0.20 & $\mathbf{0 . 6 8}$ & 0.09 \\
\hline NBPPOE & -0.08 & 0.40 & $\mathbf{0 . 8 2}$ & 0.07 & 0.02 \\
\hline CNPPOE & -0.12 & $\mathbf{0 . 8 9}$ & 0.19 & 0.04 & 0.00 \\
\hline & & & & & \\
\hline
\end{tabular}

- The fifth principal component (PC5): PC5 has a strongly positive correlation with RSME (ratio of SMEs for overall borrowers). Meanwhile, it correlates negatively with RPL (ratio of performing loan to overall loan balance). That is, the score of PC5 increase with increasing ratio of non-performing loan (RNPL). In comparison with large or major companies, SMEs have a higher risk to default. The more borrowers of SMEs, the more amount of nonperforming loans. Figure 1 shows the relation between RSME and RNPL. Except for three outliers: A1 (Ugo Sb), A3 (Aoi Mori SB) and M5 (First Bank Miyashin SB), there is a comparatively strong correlation between RSME and RNPL. The correlation coefficient between RSME and RNPL is 0.53 with $p$-value $=0.72 \%$ while the three outliers were not taken into account. Therefore, if a shinkin bank makes its efforts to increase borrowers from SMEs, it has to struggle with a comparatively high ratio of nonperforming loans. From this viewpoint, PC5 indicates how a shinkin bank place importance on loan business to SMEs. We name PC5 awareness of the importance of lending to SMEs.

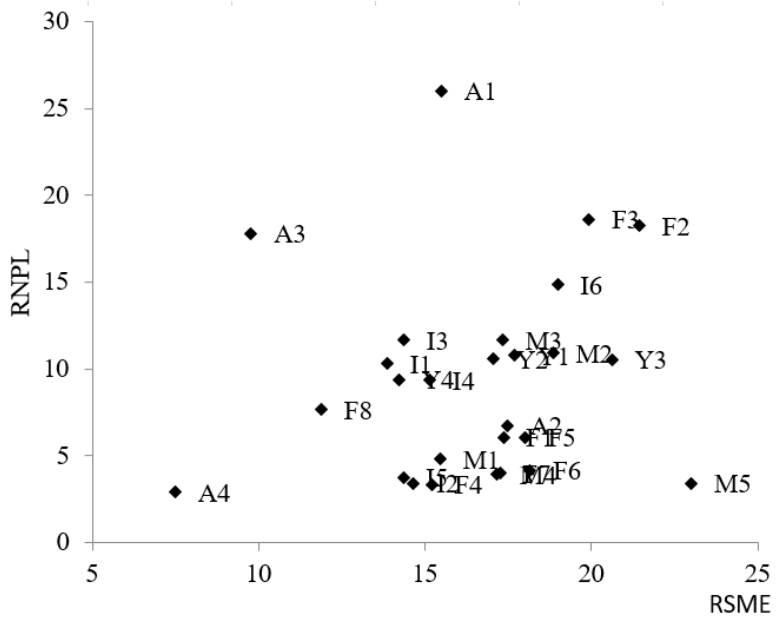

Fig. 1 Relation between RSME and RNPL

\section{Performance Assessment and Discussion}

\subsection{Ranking of Regional Financial Business Size (PC1)}

Based on the component loadings matrix shown in Table 2, we calculated scores of each shinkin bank on each principal component. Table 3 shows PC1 scores of each shinkin bank and its related performance measures, where DB, RLB, LSME and PL are given by 100 million of Japanese yuan. From Table 3, it is clear that:

- As Aoi Mori SB (A3) has the largest amount of DB (deposit balance), RLB (regional loans balance) and LSME (lending to SMEs) among the 27 shinkin banks, it ranks the first and its score is 3.695. This means that Aoi Mori SB overwhelms others largely in regional financial business size. Mori No Miyako SB (M1) places second with score of 2.225. Fukushima SB (F1) comes third with score of 1.309. These top three shinkin banks have larger DB (deposit balance), NB (number of branches) and other related performance measures.

- There are 20 shinkin banks their PC1 scores are less than zero. Miyako SB (I6) gets the lowest score of -0.959 because of its smallest NPOE, RLB, LSME, NRB, and PL, as well as less DB and NB (number of branch). In comparison, Shinjo SB has the smallest DB (deposit balance) of 6.22 billion Japanese yuan but it ranks the fourth to the lowest. This is because Shinjo SB has larger NRB (number of regional borrowers) and NBSME (number of borrowers from SMEs) than the bottom three shinkin banks.

- Although Ishinomaki SB and Abukuma SB have comparatively larger DBs of more than 20 billion Japanese yuan, their RLB (regional loans balance) and LSME (lending 
Table 3 PC1 scores and related performances

\begin{tabular}{|c|c|c|c|c|c|c|c|c|c|}
\hline Shinkin Bank & $\mathrm{PC} 1$ & DB & NB & NPOE & RLB & LSME & NRB & NBSME & PL \\
\hline Aoi Mori & 3.695 & 5,957 & 63 & 722 & 2,043 & 1,253 & 46,800 & 4,580 & 1,945 \\
\hline Mori No Miyako & 2.225 & 3,943 & 29 & 346 & 1,839 & 1,247 & 27,894 & 4,316 & 2,032 \\
\hline Fukushima & 1.309 & 3,454 & 25 & 314 & 1,262 & 753 & 17,305 & 3,008 & 1,382 \\
\hline Morioka & 0.461 & 2,384 & 25 & 255 & 811 & 598 & 14,052 & 1,953 & 992 \\
\hline Ugo & 0.382 & 1,332 & 35 & 218 & 535 & 358 & 15,596 & 2,422 & 501 \\
\hline Himawari & 0.258 & 2,218 & 16 & 206 & 833 & 651 & 7,961 & 1,711 & 855 \\
\hline Koriyama & 0.103 & 2,099 & 19 & 230 & 723 & 459 & 8,081 & 1,615 & 728 \\
\hline Too & -0.008 & 1,532 & 21 & 202 & 636 & 410 & 15,731 & 1,181 & 765 \\
\hline Ichinoseki & -0.087 & 1,970 & 15 & 245 & 661 & 436 & 10,330 & 1,517 & 773 \\
\hline Tsuruoka & -0.120 & 1,714 & 19 & 132 & 642 & 429 & 9,642 & 1,709 & 727 \\
\hline Sennan & -0.157 & 1,540 & 16 & 170 & 669 & 468 & 10,507 & 1,808 & 697 \\
\hline Aizu & -0.158 & 1,833 & 18 & 182 & 616 & 351 & 9,446 & 1,634 & 733 \\
\hline Yamagata & -0.159 & 1,156 & 15 & 179 & 671 & 409 & 8,064 & 1,665 & 638 \\
\hline Siragawa & -0.161 & 2,020 & 18 & 189 & 573 & 402 & 8,177 & 1,246 & 888 \\
\hline Sugakawa & -0.169 & 1,884 & 13 & 197 & 761 & 542 & 7,913 & 1,442 & 823 \\
\hline Akita & -0.312 & 1,262 & 18 & 176 & 542 & 301 & 9,023 & 1,579 & 600 \\
\hline Ishinomaki & -0.370 & 2,064 & 12 & 145 & 550 & 361 & 6,584 & 1,243 & 565 \\
\hline Mizuaawa & -0.399 & 1,148 & 10 & 157 & 457 & 345 & 5,106 & 736 & 481 \\
\hline Yonezawa & -0.458 & 1,165 & 13 & 155 & 458 & 298 & 8,691 & 1,485 & 468 \\
\hline Abukuma & -0.510 & 2,293 & 17 & 109 & 400 & 293 & 4,393 & 796 & 598 \\
\hline First Bank Miyashin & -0.619 & 1,193 & 13 & 159 & 460 & 365 & 3,975 & 919 & 586 \\
\hline Kisennuma & -0.646 & 1,479 & 12 & 119 & 387 & 312 & 4,405 & 766 & 415 \\
\hline Kitagami & -0.659 & 793 & 9 & 110 & 388 & 279 & 5,913 & 898 & 414 \\
\hline Shinjo & -0.699 & 622 & 9 & 93 & 342 & 226 & 5,509 & 785 & 334 \\
\hline Nihionmatu & -0.859 & 1,024 & 7 & 98 & 389 & 249 & 5,345 & 637 & 412 \\
\hline Hanamaki & -0.924 & 739 & 9 & 113 & 319 & 245 & 4,168 & 599 & 379 \\
\hline Miyako & -0.959 & 747 & 9 & 85 & 250 & 177 & 3,744 & 714 & 253 \\
\hline
\end{tabular}

to SMEs) account for a very small proportion of their DBs (deposit balance). Because of this, these two shinkin banks got negative scores for PC1. This means that the regional financing business sizes of these two shinkin banks don't match with their size of deposit balance.

\subsection{Profit-Making Ability from Non-Regional Customers and Capital Efficiency}

Table 4 shows the ranking list of the shinkin banks by PC2 scores. As described above, PC2 scores represent profit-making ability from non-regional customers. The higher PC2 score, the more profit a shinkin bank could obtained from non-regional customers. From Table 4, we can observe that:

- Among the top five shinkin banks in the list of PC2 scores, four shinkin banks, Abukuma SB (F5), Kisennuma SB (M3), Ishinomaki SB (M2) and Miyako SB (I6), suffered long-standing deflation as well as the Great East Japan Earthquake Disaster, they received many public funds.

- Except for the above four shinkin banks, there are five shinkin banks whose scores for PC2 are greater than zero. These five shinkin banks made comparatively more profit not through returns of investments in their regional customers. For example, Tsuruoka SB (Y1) made $21.36 \%$ of net business profit through service fee income and government bond trading profits etc., the return incurred by loans to regional customers accounted for $78.64 \%$ of ordinary profit. Siragawa SB (F4) obtained $32.89 \%$ of net business profit not though lending to the regional customers.

- In comparison, 18 out of 27 shinkin banks have PC2 scores that are less than zero. This means that these shinkin banks made their profit primarily through lending to regional customers. Yamagata SB (Y3) has the lowest score for PC2, it made only $6.34 \%$ of net business profit not though lending to the regional customers.

According to the ranking list of the shinkin banks by PC3 scores shown in Table 5, we can examine the capital efficiency for each shinkin bank.

- As Shinjo SB (Y4) has the highest overall profit margin (OPM) and ROA among 27 shinkin banks, it has the highest score for PC3 and thus it is the best shinkin bank in capital efficiency. In contrast, Hanamaki SB (I5) and Sugakawa SB (F6) place at the bottom two because these two shinkin banks have negative overall profit margin (OPM) and very low ROA.

- Shinjo SB (Y4) has a very low score for PC2, which means it obtains a few profit from non-regional customers. At the same time, it has the top score for PC3, which means it could achieve very high overall profit margin. As the result, Shinjo SB is excellent at obtaining profit through serving its regional customers.

- Although the overall profit margin (OPM) and ROA of Abukuma SB (F5) is not very high, it has the third highest score for PC3. This is mainly because it has the highest value of NBPPOE (net business profit per officer or employee), which come from the injection of public funds.

- More than half of the shinkin banks have negative scores for PC3. This result derives from the fact that most of the shinkin banks have comparatively lower overall profit 
Table 4 PC2 scores and related performances

\begin{tabular}{|c|c|c|c|c|c|c|c|}
\hline Shinkin Bank & PC2 & $\mathrm{EC}$ & RLDR & CNP & CAR & DBPOE & CNPPORE \\
\hline Abukuma & 3.989 & 29,273 & 17.44 & 3,779 & 40.39 & 21.04 & 34.67 \\
\hline Kisennuma & 1.279 & 18,895 & 26.17 & 971 & 33.76 & 12.43 & 8.16 \\
\hline Ishinomaki & 1.071 & 23,657 & 26.65 & 398 & 33.53 & 14.23 & 2.74 \\
\hline Tsuruoka & 0.709 & 17,917 & 37.46 & 591 & 27.66 & 12.98 & 4.48 \\
\hline Miyako & 0.657 & 11,656 & 33.47 & 526 & 36.76 & 8.79 & 6.19 \\
\hline Siragawa & 0.497 & 13,941 & 28.37 & 757 & 21.78 & 10.69 & 4.01 \\
\hline Aoi Mori & 0.456 & 26,763 & 34.30 & 1,378 & 12.43 & 8.25 & 1.91 \\
\hline Aizu & 0.195 & 11,236 & 33.61 & 757 & 17.81 & 10.07 & 4.16 \\
\hline Fukushima & 0.156 & 16,017 & 36.54 & 1,097 & 12.42 & 11.00 & 3.49 \\
\hline Ugo & -0.148 & 8,758 & 40.17 & 713 & 16.37 & 6.11 & 3.27 \\
\hline Koriyama & -0.197 & 10,123 & 34.44 & 428 & 14.81 & 9.13 & 1.86 \\
\hline Morioka & -0.235 & 10,627 & 34.02 & 229 & 11.06 & 9.35 & 0.90 \\
\hline Ichinoseki & -0.238 & 10,554 & 33.55 & 569 & 13.98 & 8.04 & 2.32 \\
\hline Too & -0.326 & 8,609 & 41.51 & 377 & 13.40 & 7.58 & 1.87 \\
\hline Himawari & -0.383 & 7,188 & 37.56 & 686 & 8.81 & 10.77 & 3.33 \\
\hline Mori No Miyako & -0.388 & 16,004 & 46.64 & 957 & 8.56 & 11.40 & 2.77 \\
\hline Mizuaawa & -0.389 & 8,727 & 39.81 & 181 & 13.43 & 7.31 & 1.15 \\
\hline Nihionmatu & -0.415 & 5,149 & 37.99 & 226 & 12.86 & 10.45 & 2.31 \\
\hline Yonezawa & -0.432 & 7,136 & 39.31 & 312 & 15.50 & 7.52 & 2.01 \\
\hline Hanamaki & -0.466 & 7,003 & 43.17 & 169 & 20.31 & 6.54 & 1.50 \\
\hline Sennnan & -0.504 & 7,558 & 43.44 & 329 & 13.21 & 9.06 & 1.94 \\
\hline Sugakawa & -0.583 & 9,670 & 40.39 & 303 & 11.31 & 9.56 & 1.54 \\
\hline Akita & -0.665 & 6,161 & 42.95 & 154 & 12.12 & 7.17 & 0.88 \\
\hline Kitagami & -0.669 & 5,497 & 48.93 & 134 & 16.09 & 7.21 & 1.22 \\
\hline First Bank Miyashin & -0.732 & 5,337 & 38.56 & 229 & 9.27 & 7.50 & 1.44 \\
\hline Shinjo & -1.006 & 4,404 & 54.98 & 210 & 10.70 & 6.69 & 2.26 \\
\hline Yamagata & -1.233 & 5,142 & 58.04 & 259 & 9.67 & 6.46 & 1.45 \\
\hline
\end{tabular}

Table 5 PC3 scores and related performances

\begin{tabular}{|l|r|r|r|r|}
\hline \multicolumn{1}{|c|}{ Shinkin Bank } & \multicolumn{1}{c|}{ PC3 } & \multicolumn{1}{c|}{ OPM } & \multicolumn{1}{c|}{ ROA } & NBPPOE \\
\hline Shinjo & 3.712 & 1.10 & 1.22 & 7.32 \\
\hline Fukushima & 1.166 & 0.35 & 0.52 & 5.87 \\
\hline Abukuma & 0.933 & 0.28 & 0.36 & 7.41 \\
\hline Kitagami & 0.886 & 0.26 & 0.42 & 6.06 \\
\hline Mori No Miyako & 0.840 & 0.26 & 0.38 & 4.65 \\
\hline Yamagata & 0.788 & 0.43 & 0.42 & 3.01 \\
\hline Mizuaawa & 0.758 & 0.26 & 0.31 & 7.20 \\
\hline Too & 0.203 & 0.34 & 0.29 & 3.27 \\
\hline Ugo & 0.054 & 0.28 & 0.27 & 2.82 \\
\hline Miyako & 0.049 & 0.13 & 0.33 & 5.14 \\
\hline Himawari & 0.030 & 0.19 & 0.28 & 3.52 \\
\hline Aizu & -0.030 & 0.25 & 0.30 & 3.48 \\
\hline Tsuruoka & -0.124 & 0.10 & 0.19 & 3.98 \\
\hline Kisennuma & -0.164 & 0.17 & 0.30 & 4.51 \\
\hline Sennan & -0.255 & 0.19 & 0.22 & 2.62 \\
\hline Siragawa & -0.378 & 0.10 & 0.27 & 3.44 \\
\hline Akita & -0.485 & 0.17 & 0.17 & 2.09 \\
\hline Ishinomaki & -0.531 & 0.17 & 0.23 & 3.85 \\
\hline Aoi Mori & -0.588 & 0.15 & 0.15 & 2.40 \\
\hline Morioka & -0.672 & 0.08 & 0.17 & 2.44 \\
\hline Yonezawa & -0.680 & 0.08 & 0.20 & 2.01 \\
\hline Koriyama & -0.743 & 0.07 & 0.18 & 2.19 \\
\hline Nihionmatu & -0.798 & 0.10 & 0.16 & 1.63 \\
\hline First Bank Miyashin & -0.848 & 0.05 & 0.18 & 1.60 \\
\hline Ichinoseki & -0.904 & 0.11 & 0.18 & 1.81 \\
\hline Hanamaki & -0.953 & -0.04 & 0.09 & 2.19 \\
\hline Sugakawa & -1.265 & -0.03 & 0.07 & 1.10 \\
\hline & & & & \\
\hline & & & & \\
\hline
\end{tabular}

margin and ROA. There are only four of 27 shinkin banks that overall profit margin is larger than $0.3 \%$. Meanwhile, there are also only four ones that ROA is larger than $0.4 \%$. Therefore, it is an urgent business issue for most of the shinkin banks to manipulate their funds effectively and improve their capital efficiency.

\subsection{Business Efficiency and Awareness of the Importance of Lending to SMEs}

Table 6 shows the ranking list of the shinkin banks by PC4 scores. As PC4 is most strongly correlated with LBPB (loans balance per branch, principal component loading=0.92) and second strongly correlated with DBPB (deposits balance per branch, principal component loading $=0.79$ ), PC4 scores represent mainly the business efficiency for each branch. From Table 6 , we can observe that:

- Mori No Miyako SB (M1), Sugakawa SB (F6), Himawari SB (F2), Fukushima SB (F1) and Nihonmatu SB (F8) have high scores for PC4 and rank the top five in the list. This is mainly because these five shinkin banks have more than 5.8 billion Japanese yuan of loans balance each branch, and also have more than 13 billion Japanese yuan of deposits balance each branch, and thus their business efficiency is very high.

- Nihonmatu SB (F8), which has the smallest branch number of seven, ranks the fifth by PC4 scores. In contrast, Ugo SB (A1), Aoi Mori SB (A3) and Miyako SB (I6) are the top three in branch's number, but these three shinkin banks place the bottom 3 by PC4 scores. Because the operations of shinkin banks are limited strictly into the licensed area, the more their branch's number, the narrower the area and the less the customers for each branch's operation. This suggests that there should be an appropriate number of branch for a shinkin bank. 
Table 6 PC4 scores and related performances

\begin{tabular}{|l|c|c|c|c|}
\hline \multicolumn{1}{|c|}{ Shinkin Bank } & PC4 & LBPB & DBPB & LBPOE \\
\hline Mori No Miyako & 2.208 & 73.62 & 135.97 & 6.17 \\
\hline Sugakawa & 1.392 & 66.00 & 144.92 & 4.36 \\
\hline Himawari & 1.231 & 65.38 & 138.63 & 5.08 \\
\hline Fukushima & 1.130 & 58.88 & 138.16 & 4.69 \\
\hline Nihionmatu & 1.021 & 63.71 & 146.29 & 4.55 \\
\hline Ishinomaki & 0.780 & 52.83 & 172.00 & 4.37 \\
\hline Siragawa & 0.481 & 51.00 & 112.22 & 4.86 \\
\hline Abukuma & 0.294 & 37.41 & 134.88 & 5.83 \\
\hline First Bank Miyashin & 0.272 & 46.69 & 91.77 & 3.82 \\
\hline Ichinoseki & 0.268 & 53.33 & 131.33 & 3.27 \\
\hline Tsuruoka & 0.265 & 42.95 & 90.21 & 6.18 \\
\hline Sennan & 0.190 & 45.31 & 96.25 & 4.26 \\
\hline Mizuaawa & 0.090 & 54.50 & 114.80 & 3.47 \\
\hline Kitagami & 0.014 & 50.67 & 88.11 & 4.15 \\
\hline Aizu & -0.013 & 42.39 & 101.83 & 4.19 \\
\hline Yamagata & -0.078 & 47.53 & 77.07 & 3.98 \\
\hline Morioka & -0.217 & 44.24 & 95.36 & 4.34 \\
\hline Koriyama & -0.227 & 47.16 & 110.47 & 3.90 \\
\hline Kisennuma & -0.365 & 39.08 & 123.25 & 3.94 \\
\hline Hanamaki & -0.422 & 43.67 & 82.11 & 3.48 \\
\hline Shinjo & -0.526 & 41.00 & 69.11 & 3.97 \\
\hline Yonezawa & -0.637 & 40.31 & 89.62 & 3.38 \\
\hline Akita & -0.721 & 35.72 & 70.11 & 3.65 \\
\hline Too & -0.818 & 37.48 & 72.95 & 3.90 \\
\hline Miyako & -1.149 & 33.00 & 83.00 & 3.49 \\
\hline Aoi Mori & -1.685 & 37.62 & 94.56 & 3.28 \\
\hline Ugo & -2.778 & 19.40 & 38.06 & 3.11 \\
\hline
\end{tabular}

- Ugo SB (A1) got the lowest score of PC4. This is because that the LBPB of Ugo SB is only 1.9 billion Japanese yuan and its DBPB is just 3.8 billion Japanese yuan; both of these two performances are much less than other shinkin banks. This means that Ugo SB should revise its branch location and it is desirable to merge or close several branches in order to improve its operations efficiency and simultaneously not impair the convenience of its customers.

Table 7 shows the ranking list of the shinkin banks by PC5 scores, which represent awareness of the importance of lending to SMEs. According to the result of table 7, it is clear that:

- The top three in the list are Himawari SB (F2), Koriyama SB (F3) and Ugo SB (A1). These three shinkin banks have comparatively higher RSME (ratio of SMEs for overall borrowers) of more than $15 \%$. In particular, they have the lowest RPL (ratio of performing loan to overall loan balance). In other word, these three SBs are the top three worst in the ratio of non-performing loans, which range from $18.26 \%$ to $26.01 \%$.

- Because Too SB (A4) has the lowest RSME (ratio of SMEs for overall borrowers) of only $7.48 \%$ and at the same time, it has the highest RPL (ratio of performing loan to overall loan balance) of $97.10 \%$, it got the lowest score for PC5. From the viewpoint of risk management, it is desirable to avoid occurring of non-performing loans or to raise RPL. To do this, some financial institutions including some shinkin banks have been engaged in curbing loans to SMEs because SMEs have higher risk to default. This leads to the weakening of shinkin banks' role in the regional economies.
Table 7 PC5 scores and related performances

\begin{tabular}{|l|c|c|c|}
\hline \multicolumn{1}{|c|}{ Shinkin Bank } & PC5 & RSME(\%) & RPL $(\%)$ \\
\hline Himawari & 2.207 & 21.44 & 81.74 \\
\hline Koriyama & 1.694 & 19.93 & 81.39 \\
\hline Ugo & 1.386 & 15.50 & 73.99 \\
\hline Yamagata & 1.128 & 20.62 & 89.46 \\
\hline Miyako & 0.925 & 18.98 & 85.16 \\
\hline First Bank Miyashin & 0.713 & 23.01 & 96.59 \\
\hline Ishinomaki & 0.680 & 18.84 & 89.08 \\
\hline Tsuruoka & 0.628 & 17.70 & 89.23 \\
\hline Kisennuma & 0.266 & 17.33 & 88.34 \\
\hline Yonezawa & 0.170 & 17.05 & 89.43 \\
\hline Fukushima & 0.114 & 17.36 & 93.95 \\
\hline Mori No Miyako & -0.046 & 15.46 & 95.21 \\
\hline Sugakawa & -0.046 & 18.16 & 95.86 \\
\hline Akita & -0.101 & 17.47 & 93.25 \\
\hline Kitagami & -0.202 & 15.15 & 90.64 \\
\hline Mizuaawa & -0.236 & 14.37 & 88.34 \\
\hline Abukuma & -0.281 & 18.00 & 93.96 \\
\hline Sennan & -0.308 & 17.17 & 96.07 \\
\hline Morioka & -0.389 & 13.87 & 89.70 \\
\hline Aizu & -0.414 & 17.25 & 96.00 \\
\hline Shinjo & -0.434 & 14.22 & 90.60 \\
\hline Aoi Mori & -0.576 & 9.78 & 82.20 \\
\hline Siragawa & -0.884 & 15.20 & 96.65 \\
\hline Ichinoseki & -1.093 & 14.66 & 96.59 \\
\hline Nihionmatu & -1.099 & 11.89 & 92.35 \\
\hline Hanamaki & -2.675 & 7.49 & 97.10 \\
\hline Too & & & \\
\hline
\end{tabular}

- Aoi Mori SB (A3) has the fourth worst RPL of $82.20 \%$ or the fourth highest ratio of non-performing loan to overall loan balance. However, it ranks only the sixth from the bottom in the ranking list of the shinkin banks by PC5 scores, because it has the second worst RSME.

From the above results, it is clear that PC5 scores can be used to assess whether a shinkin bank has tolerated the regional risk to make its endeavor to serve regional SMEs.

\section{Evaluating Regional Contribution}

\subsection{Regional Contribution Index}

We have obtained five principal components in section 3; each of them provides a measure to express a principal feature of the original dataset. Because there is zero correlation between these components, we can define an index to evaluate shinkin banks' regional contribution based on the scores of these five principal components. Among the five components, PC2 indicates the profit-making ability from non-regional customers; PC3 provides a measure for shinkin banks' capital efficiency or investment efficiency, and PC4 scores are the measure of business efficiency, these three components do not directly relate to shinkin banks' regional contribution. Whereas, PC1 scores give a measure of shinkin banks' business size targeting regionbased relationship banking, PC5 is a measure of how shinkin banks are aware of the importance of lending to SMEs. Thus, the scores of PC1 and PC5 are two measures directly relating to shinkin banks' regional contribution.

According to the interpretation of PC1 and PC5, and also considering the scores for each component have been standardized to zero mean and unit variance, we can define shinkin banks' regional contribution index, RCI, as the following equation (1). 


$$
R C I_{i}=P C_{1 i} \times W_{1}+P C_{5 i} \times W_{5} ; i=1,2, \cdots, 27
$$

where subindex $i$ stands for the $i$ th shinkin bank, $R C I_{i}$ is the regional contribution index, $P C_{1 i}$ is the score for $P C 1$ and $P C_{5 i}$ is the score for PC5. $W_{1}$ and $W_{5}$ are weights on $\mathrm{PC} 1$ scores and PC5 scores respectively, their values are decided according to proportion of the variance that PC1 and PC5 have accounted for. If $P V_{1}$ and $P V_{5}$ be the proportion of the variance accounted through PC1 and PC5 respectively, we have:

$$
W_{k}=\frac{P V_{k}}{P V_{1}+P V_{5}} ; k=1,5
$$

In this study, we could obtain $W_{1}=0.881$ and $W_{5}=0.119$.

\subsection{Ranking of Shinkin Banks by RCI}

Based on equation (1), we could calculate the regional contribution index RCI for each shinkin bank and give the ranking of shinkin banks by RCI as shown in Table 8 . From this table, it is clear that:

\begin{tabular}{|c|c|c|c|}
\hline Shinkin Bank & RCI & Rank by RCI & Rank by PC1 \\
\hline Aoi Mori & 3.626 & 1 & 1 \\
\hline Mori No Miyako & 2.219 & 2 & 2 \\
\hline Fukushima & 1.322 & 3 & 3 \\
\hline Ugo & 0.547 & 4 & 5 \\
\hline Himawari & 0.520 & 5 & 6 \\
\hline Morioka & 0.415 & 6 & 4 \\
\hline Koriyama & 0.305 & 7 & 7 \\
\hline Yamagata & -0.025 & 8 & 13 \\
\hline Tsuruoka & -0.045 & 9 & 10 \\
\hline Sugakawa & -0.175 & 10 & 15 \\
\hline Sennnan & -0.194 & 11 & 11 \\
\hline Aizu & -0.208 & 12 & 12 \\
\hline Ichinoseki & -0.217 & 13 & 9 \\
\hline Siragawa & -0.266 & 14 & 14 \\
\hline Ishinomaki & -0.289 & 15 & 17 \\
\hline Akita & -0.324 & 16 & 16 \\
\hline Too & -0.326 & 17 & 8 \\
\hline Mizuaawa & -0.427 & 18 & 18 \\
\hline Yonezawa & -0.438 & 19 & 19 \\
\hline First Bank Miyashin & -0.534 & 20 & 21 \\
\hline Abukuma & -0.544 & 21 & 20 \\
\hline Kisennuma & -0.614 & 22 & 22 \\
\hline Kitagami & -0.683 & 23 & 23 \\
\hline Shinjo & -0.751 & 24 & 24 \\
\hline Miyako & -0.849 & 25 & 27 \\
\hline Nihionmatu & -0.989 & 26 & 25 \\
\hline Hanamaki & -1.058 & 27 & 26 \\
\hline
\end{tabular}

Table 8 Ranking of Shinkin Banks by RCI

- As PC5 contributes only $4.978 \%$ of the total variance, the rank order of 27 shinkin banks by RCI is very similar to the ranking by $\mathrm{PC} 1$ scores. 13 out of 27 shinkin banks are the same rank orders in the RCI ranking as in the PC1 ranking. The rank orders of seven shinkin banks in the ranking by RCI are only one order different from their orders in the ranking by $\mathrm{PC} 1$ scores.

- The top three in the ranking by RCI are Aoi Mori SB, Mori No Miyako SB and Fukushima SB because these three shinkin banks have very high scores for PC1. This suggests that if the regional financial business size of a shinkin bank is very large, it plays a very important role in the regional economies and has as well a very large contribution to the regional development.

- Comparing to the rank order by PC1 scores, the rank order of Yamagata SB and Sugakawa SB in the ranking by RCI improved five orders. This is because that these two shinkin banks have comparatively higher RSME (ratio of SMEs for overall borrowers). It suggests that these two shinkin banks have made more efforts to lending to SMEs, relative to their regional financial business size.

- On the contrary, there are two shinkin banks: Ichinoseki SB and Too SB that their rank order in the ranking by RCI are much lower than their orders in the ranking by PC1 scores. This means that these two shinkin banks have not provided enough lending to SMEs proportional to their regional financial business size.

- There are only seven shinkin banks out of 27 that their RCI are positive, 20 shinkin banks have negative RCI values. This means that there is a large difference in the regional contribution among the 27 shinkin banks and most of them are facing the issue to expand their regional business size and pay more attention to lending to SMEs.

\section{Conclusion}

This paper aimed to apply principal components analysis to examine the performance of shinkin banks' contribution to regional economies in northeast area of Japan. Different from the existing studies, this paper is the first attempt to use principal components analysis to analysis of shinkin banks. Meanwhile, we limit our analysis to 27 shinkin banks in the northeast area of Japan and put our emphasis on extracting an effective index to measure the contributions of the shinkin banks to regional economies.

The main results can be summarized as the following:

(1) According to the KMO test, we selected 23 out of 26 performance measures to conduct PCA. As the result, we could extract five principal components, which summarized $89.17 \%$ of the information contained in 23 original performance measures. The first principal component (PC1) accounts for $36.87 \%$ and the second principal component (PC2) accounts for $21.82 \%$ of the variance of the 23 original performance measures.

(2) According to the component loadings matrix, we named PC1 the measure of regional financial business size, PC2 the measure of profit-making ability from non-regional customers, PC3 capital efficiency, PC4 business efficiency, and PC5 awareness of the importance of lending to SMEs.

(3) From the viewpoint of regional financial business size, Aoi Mori SB (A3) is overwhelmingly the largest among 27 shinkin banks. Mori No Miyako SB (M1) places second and Fukushima SB (F1) comes third in the ranking. In contrast, the PC1 scores of 20 shinkin banks rang from 0.959 to -0.008 and there are comparatively less difference in the regional financial business size among them. 
(4) Except for four shinkin banks suffered long-standing deflation as well as the Great East Japan Earthquake Disaster and received many public funds, 18 out of 27 shinkin banks have PC2 scores that are less than zero. It suggests that most of the shinkin banks have lacked channels to make profit from non-regional customers.

(5) According the scores for PC3, Shinjo SB has the extreme score of 3.712 and it is excellent at obtaining profit through serving its regional customers. However, more than half of the shinkin banks suffered from very low capital efficiency. It is an urgent business issue for most of the shinkin banks to manipulate their fuds effectively and improve their capital efficiency.

(6) From the viewpoint of business efficiency, the best five are Mori No Miyako SB (M1), Sugakawa SB (F6), Himawari SB (F2), Fukushima SB (F1) and Nihonmatu SB (F8). On the contrary, Ugo SB (A1) is the worst. Ugo SB (A1) merged Akita Fureai Shinkin bank in 2009 and then it remains an issue to revise its branch location and improve the operation efficiency for each branch.

(7) According the scores for PC5, we can make clear how a shinkin bank has endeavored to lending to regional SMEs. Among 27 shinkin banks, the best three are Himawari SB (F2), Koriyama SB (F3) and Ugo SB (A1). Too SB (A4) has a very large negative score of -2.675 and ranks the lowest place.

(8) Based on the scores for PC1 and PC5, we proposed an index RCI to assess the performance of shinkin banks' regional contribution. According to RCI values, Aoi Mori SB, Mori No Miyako SB and Fukushima SB are the top three and they have contributed largely to the regional economies.

The above results were obtained on the condition that we limited our analysis to 27 shinkin banks in the northeast area of Japan. The analyzing method and process used in this paper are also applicable to analyze shinkin banks in other areas. However, as there is a wide variety in regional economies, the results of PCA vary usually in accordance with areas.

\section{Acknowledgments}

This work was partly supported by Grant-in-Aid for Scientific Research (C) from the Japan Society for the Promotion of Science under Grant No.25380497 and No.16K03848.

\section{References}

[1] Takigawa Yoshio (2004). What is Regional Bank? What are the Goals of Regional Bank? The annuals of economic studies, Kobe University, 51, 1-16.

[2] Iwasa Yoichi (2008). Revitalization of Regional Economies and the Role of Financial System (I). The business review of Kansai University, 52 (6), 21-40. [in Japanese]

[3] Iwasa Yoichi (2008). Revitalization of Regional Economies and the Role of Financial System (II). The business review of Kansai University, 53 (1), 1-20. [in Japanese]

[4] Kiyotsugu Yoshihara (2009). Utility and the Problem of the Regional Economy of the Sinkin-Bank Comparing Management Indexes with the Economic Power of Local Business. So- cial systems studies (Ritsumeikan University), 19, 149-175. [in Japanese]

[5] Horie Yasuhiro (2010). On the measurement of operation areas and profitability for Shinkin Banks. Keizaigaku kenkyu or Journal of political economy (Kyushu University), 76 (5), 7-42. [in Japanese]

[6] Ishikawa Kiyohide (2012). Management Behaviors in Failed Shinkin Bank: An Analysis of the Failing Factors of Sogo Shinkin Bank. Ryukoku business review, Ryukoku University, 13, 1-20. [in Japanese]

[7] Shimabukuro Itsuko (2003). Empirical Analysis about activity of Shinkin-banks and Credit unions Under Heisei-Depression. Journal of Personal Finance and Economics, 18, 219-227. [in Japanese]

[8] Horie Yasuhiro (2013). Empirical Analysis of Profitability and the Loss on Disposal of Distressed Assets in Shinkin Banks and Credit Cooperatives. Keizaigaku kenkyu or Journal of political economy (Kyushu University), 79 (5-6), 1-36. [in Japanese]

[9] Kozuka Masafumi (2014). Lending Behavior for SmallMedium Business by Shinkin Bank and Other Domestic Bank in Japan : Evidences from Time Series Data. Journal of the University of Marketing and Distribution Sciences Economics, informatics \& policy studies, 22 (2), 19-32. [in Japanese]

[10] Yamori, Nobuyoshi, et al. (2013). Japanese banking regulations and SME finance under the global financial crisis. Japanese Journal of Monetary and Financial Economics, 1 (1), 59-90.

[11] Masaji Kano and Yoshiro Tsutsui (2003). Geographical segmentation in Japanese bank loan markets. Regional Science and Urban Economics, 33 (2), 157-174.

[12] Hong Liu and John O. S. Wilson (2010). The profitability of banks in Japan. Applied Financial Economics, 20 (24), 18511866.

[13] Liu Hong and John OS Wilson (2013). Competition and risk in Japanese banking. The European Journal of Finance, 19 (1), $1-18$.

[14] A. George Assaf, Carlos P. Barros, and Roman Matousek (2011). Productivity and efficiency analysis of Shinkin banks: Evidence from bootstrap and Bayesian approaches. Journal of Banking and Finance, 35 (2), 331-342.

[15] Dai Jianzhong (2014). Robust Estimation of Productivity Changes in Japanese Shinkin Banks. Eurasian journal of business and economics, 7 (13), 69-90.

[16] Victor Shih, Qi Zhang, and Liu Mingxing (2007). Comparing the performance of Chinese banks: a principal component approach. China Economic Review, 18 (1), 15-34.

[17] Ho, Chien-Ta Bruce, and Desheng Dash Wu (2009). Online banking performance evaluation using data envelopment analysis and principal component analysis. Computers \& Operations Research, 36 (6), 1835-1842.

[18] Cristina Badarau-Semenescu and Gregory Levieuge (2010). Assessing The Potential Strength Of A Bank Capital Channel In Europe: A Principal Component Analysis. The Review of Finance and Banking, 2 (1), 5-16.

[19] Hajialiakbari, F., Gholami, M. H., Roshandel, J., and HatamiShirkouhi, L. (2013). Assessment of the effect on technical efficiency of bad loans in banking industry: a principal component analysis and neuro-fuzzy system. Neural Computing and Applications, 23(1), 315-322.

[20] Marinc Matej, Mojmir Mrak, and Vasja Rant (2014). Dimensions of bank capital regulation: a cross-country analysis. Panoeconomicus, 4, 415-439. 
Hideo SATO

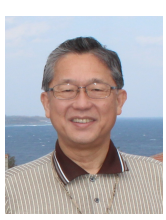

was a Ph.D candidate of Graduate School of Symbiotic System Science, Fukushima University. He was the Executive Managing Director in Fukushima Shinkin Bank. He would be writing his doctoral dissertation right now if he had not passed away suddenly due to illness in January 2016. He received his master degree in economics and business administration from Fukushima University in Japan. He was not only a honest, excellent business leader and entrepreneur, but also a warm-hearted social activist. He made a great contribution to the development of regional economies, and social prosperity in Fukushima prefecture, Japan. We pray that his soul may rest in peace.

\section{Yanwen Dong}

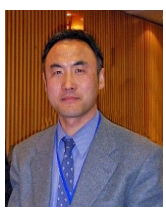

is a professor in the cluster of science and technology at Fukushima University. He received his bachelor degree in 1982 and a master degree in 1984 from University of Science and Technology Beijing, China. He also received Ph.D in 1996 from the Osaka Prefecture University, Japan. He worked in University of Science and Technology Beijing as a lecture from 1984 to 1995 and in Faculty of Economics, Fukushima University as an associate professor from 1997 to 2004. His current research interests include cell production system, production scheduling, data mining and management information system.

\section{Vinod Kumar}

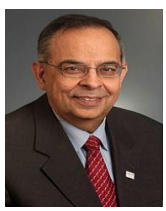

is now a professor in technology and operations management at the Sprott School of Business, and head of manufacturing systems center at Carleton University. He is the winner of the two Scholarly Achievement and three Research Achievement Awards of Carleton University, received his graduate education from the University of California, Berkeley and the University of Manitoba. He has just completed ten years as the Director of the Sprott School of Business, Carleton University. Vinod has also served for several years on the Board of Governors and the Senate for Carleton University and on the Board of the Ontario Network of e-Commerce. 